\title{
VIABILIDADE DO SISTEMA DE PRODUÇÃO DE MUDAS EM BANDEJAS EM TRESS CULTIVARES DE CEBOLA
}

\author{
Viability of onion seedling production on polyestyrene trays in three cultivars \\ Marie Yamamoto Reghin ${ }^{1}$, Rosana Fernandes Otto ${ }^{1}$, Jean Ricardo Olinik², \\ Carlos Felipe Stülp Jacoby ${ }^{3}$
}

\begin{abstract}
RESUMO
O presente trabalho foi conduzido em Ponta Grossa (PR), com o objetivo de avaliar a viabilidade do sistema de produção de mudas em bandejas, comparativamente ao sistema convencional, em canteiros, em três cultivares de cebola. $\mathrm{O}$ delineamento experimental foi o de blocos casualizados com três repetições. Os tratamentos foram arranjados segundo esquema fatorial $3 \times 3$, sendo três tipos de mudas (de bandeja com 200 e com 288 células e da sementeira) e três cultivares (Mercedes, Bola Precoce e Crioula). A produção de mudas em bandejas foi conduzida sob cultivo protegido e da sementeira em ambiente natural. A semeadura ocorreu no dia 15/05/ 2004, nas bandejas e na sementeira. Aos 57 dias, as mudas foram avaliadas e transplantadas em parcelas com quatro fileiras de plantas arranjadas no espaçamento de $0,40 \times 0,08 \mathrm{~m}$, perfazendo um estande de 312.500 plantas.ha $^{-1}$. A colheita foi realizada de acordo com a maturação das plantas. Após a cura, avaliou-se a produtividade de bulbos e foram calculados os custos de produção dos diferentes tipos de mudas e a sua viabilidade. Observou-se que as mudas provenientes de bandejas apresentaram superioridade quando comparadas às da sementeira, obtendo destaque as obtidas em 200 células. A qualidade superior dessa muda refletiu-se no desempenho posterior, obtendo-se maior rendimento de bulbos com mudas de bandejas de 200 células. O desempenho foi intermediário, quando proveniente de bandejas de 288 células e inferior, quando a muda usada foi de sementeira. Destaca-se que o aproveitamento de mudas da sementeira durante a seleção foi baixo (50\%), e o custo para sua produção é alto quando se utiliza semente de híbrido, comparável ao custo de cultivar de polinização aberta em bandejas de 288 células. As cultivares mais produtivas foram Crioula e Mercedes. A produção de mudas em bandejas, principalmente na de 200 células, é viável e representa uma alternativa para aumento da produtividade no cultivo da cebola em um mercado cada vez mais competitivo.
\end{abstract}

Termos para indexação: Allium cepa L., produção de mudas, bandejas de poliestireno expandido, rendimento de bulbos.

\begin{abstract}
The present trial was realized in Ponta Grossa (PR) and aimed to evaluate the viability of onion seedling production in polyestyrene trays, compared to conventional system on seedbed, using three cultivars The experimental design used was a randomized block with three replications. The treatments were arranged in a factorial scheme $3 \times 3$, being three seedlings type (from trays with 200 and 288 cells and from seedbed), and three cultivars (Mercedes, Bola Precoce and Crioula). Seedlings production on trays were realized under protected cultivation and seedlings from seedbeds produced in the field. Seeds were sowed in May, $15^{\text {th }}$. At 57 days the seedlings were evaluated and then transplanted in plots with four rows and plants arranged in $0,40 \mathrm{x} 0,08 \mathrm{~m}$, with 312.500 plants.ha ${ }^{-1}$. The harvest was realized according to the plant maturation stage. Bulbs were dried and then yield were evaluated. The production cost and seedlings viability were calculated. It was observed the seedlings from trays were superior when compared to seedlings from seedbed, mainly those from 200 cells. This higher seedling quality reflected on later performance obtaining the highest yield from trays of 200 cells. It was intermediary with 288 trays and lower from seedbed seedling. It was observed low seedling useful from seedbed during the selection process (50\%). In the case of hybrid the cost of seedling production in seedbed was high, almost comparable to seedling production of open pollinated cultivars on trays of 288 cells. The best cultivars were Crioula and Mercedes. Seedlings production on trays mainly on 200 cells showed viability and represents an important alternative to increase onion yield in a competitive market.
\end{abstract}

Index terms: Allium cepa L., seedlings production, polyestyrene trays, bulbs yield.

(Recebido em 10 de janeiro de 2006 e aprovado em 8 de janeiro de 2007)

\section{INTRODUÇÃo}

A cebola destaca-se entre as várias espécies olerícolas pelo volume de consumo e valor econômico. A nível mundial, está incluída entre as três mais importantes olerícolas, ao lado da batata e do tomate.

O Brasil é o nono produtor mundial dessa olerícola, com volume total de produção de $1.175 .100 \mathrm{t}$, produtividade de 15,7 t.ha $^{-1}$, tendo 67.000 hectares de área plantada (FAO, 2004). Dentre os estados brasileiros, Santa Catarina tem a liderança em área cultivada e produção, tendo em 2001, $38,09 \%$ do total produzido no País, seguido em ordem decrescente, pelos Estados de São Paulo, Rio Grande do Sul, Paraná e Bahia.

\footnotetext{
'Doutoras, Professoras Adjunto de Olericultura - Departamento de Fitotecnia e Fitossanidade - Universidade Estadual de Ponta Grossa/UEPG Avenida Carlos Cavalcanti, 4748 - Campus de Uvaranas - 84030-900 - Ponta Grossa, PR - freghin@convoy.com.br, rfotto@uepg.br

${ }^{2}$ Mestrando - Departamento de Fitotecnia e Fitossanidade - Universidade Estadual de Ponta Grossa/UEPG - Avenida Carlos Cavalcanti, 4748 Campus de Uvaranas - 84030-900 - Ponta Grossa, PR - jeolinik@yahoo.com.br - Bolsista da CAPES.
}

'Engenheiro Agrônomo - felipejacoby@ibest.com.br 
No Estado do Paraná, a cebola ocupa posição de destaque, tendo apresentado na safra 2004/2005, 6.350 hectares, com rendimento médio de 13,76 t.ha ${ }^{-1}$ (SEAB/ DERAL, 2005). A baixa produtividade é decorrente entre outros fatores, da utilização de mudas de má qualidade.

A cultura da cebola pode ser estabelecida pela semeadura direta, por bulbinhos e por mudas produzidas em bandejas e mudas de raízes nuas (FONTES \& SILVA, 2002), sendo predominante a utilização de mudas de raízes nuas obtidas em sementeira.

No Estado do Paraná, a semeadura em sementeira é realizado principalmente nos meses de maio e junho, quando predominam temperaturas baixas, as quais promovem atraso no desenvolvimento das mudas. Além disso, a ocorrência de geadas é freqüente nessa época, ocasionando danos nas plântulas e prejudicando sua qualidade ou mesmo a perda das mudas nas sementeiras. O tempo para a obtenção de mudas para o transplante em campo aberto é de 70 - 90 dias. Neste período, como as plântulas ficam submetidas a riscos maiores de ocorrências de doenças, sobretudo pela própria idade e pela maior densidade populacional na sementeira, os produtores têm usado alta freqüência de pulverizações, no intuito de obter mudas com sanidade. Em Santa Catarina, a qualidade de mudas da sementeira vem sendo afetada por vários fatores, dentre eles, o tombamento e as doenças foliares (EPAGRI, 1995).

Além disso, no momento do transplante, observase que mudas com tamanhos bastante variáveis são transplantadas para o campo, o que corrobora a desuniformidade do estande e do desenvolvimento no campo.

Oliveira et al. (1993) citam que o sucesso do cultivo começa pela obtenção de mudas com boa qualidade, pois aquelas mal formadas darão origem a plantas com produção abaixo do seu potencial genético.

$\mathrm{Na}$ atualidade, produzir mudas de alta qualidade é uma das etapas mais importantes do sistema produtivo. Além de outras técnicas, a utilização dessas mudas torna a exploração olerícola mais competitiva e, conseqüentemente, mais rentável.

O sistema de bandejas proporciona maior cuidado na fase de germinação e emergência, porque a atividade é desenvolvida sob ambiente protegido, eliminando o risco de geadas na fase inicial da cultura, além de proporcionar menor custo no controle de pragas e doenças, alto índice de pegamento após o transplante e maior uniformidade no campo.

Nos países com produção intensiva de hortaliças com alta tecnologia, a produção de mudas em recipientes é feita por produtores especializados nessa atividade (LÓPEZ et al., 1999; NICOLA \& BASOCU, 2000). No Brasil, esse segmento está em fase de expansão, principalmente na região centro-sul (COSTA, 2000; ULLÉ, 2001). Tanto que, o uso de bandejas em cebola somente tem sido relatado em cultivos específicos, tendo apresentado resultados positivos, como na produção de bulbinhos (CARDOSO \& COSTA, 1999) e na produção de mudas para cultivo no verão (VINCENZO \& TESSARIOLI NETO, 2003).

A muda produzida em bandejas é considerada o método mais eficiente na Holanda e no Canadá porque confere maior uniformidade da muda de cebola, evitando a competição entre plantas observada usualmente na sementeira. Além disso, não há estresse nas raízes durante o transplante (JAIME et al., 2001).

$\mathrm{Na}$ Itália, quando foram comparados os sistemas de semeadura direta, transplante de mudas provenientes de sementeira e de bandejas, Dellacecca et al. (2000) observaram que o rendimento de bulbos foi maior quando as mudas foram obtidas em bandejas.

Na produção de mudas em bandejas, o tamanho da célula é um dos fatores que influencia diretamente o desenvolvimento e a arquitetura do sistema radicular (LATIMER, 1991). Diferentes tamanhos de célula proporcionarão mudas com diferentes tamanhos para o transplante.

Na Flórida e no Texas, Leskovar \& Vavrina (1999) observaram que mudas produzidas em volume de $4,0 \mathrm{~cm}^{3}$ apresentaram redução de $16 \%$ no rendimento de bulbos, comparadas às mudas obtidas em volume de $7,1 \mathrm{~cm}^{3}$.

O presente trabalho teve como objetivo avaliar a viabilidade do sistema de produção de mudas em bandejas, comparativamente ao sistema convencional em canteiros, em três cultivares de cebola, Mercedes, Bola Precoce e Crioula.

\section{MATERIAL E MÉTODOS}

O presente trabalho foi conduzido em Ponta Grossa (PR), localizada a $880 \mathrm{~m}$ de altitude, em solo classificado como Cambissolo Háplico Tb Distrófico típico de textura argilosa.

A etapa de produção de mudas de cebola em bandejas foi conduzida sob cultivo protegido em estufa tipo arco cobertas com filme plástico de polietileno. As bandejas foram preenchidas com substrato Plantmax®. A semeadura ocorreu no dia 15/05/2004, nas bandejas e na sementeira. Nas bandejas, usou-se duas sementes por célula e após a emergência, fez-se o desbaste, deixando-se uma muda por célula. $\mathrm{O}$ canteiro usado como sementeira localizou-se em ambiente aberto. $\mathrm{Na}$ sementeira, 
previamente, fez-se o preparo do solo com enxada rotativa e a incorporação do adubo, na fórmula 5-20-20 (100 g.m $\left.\mathrm{m}^{-2}\right)$. As sementes foram colocadas em sulcos com profundidade de 1,0 cm, espaçados $10 \mathrm{~cm}$ entre si. A densidade de semeadura na sementeira foi $5 \mathrm{~g} \cdot \mathrm{m}^{-2}$. Os tratos culturais abrangeram a irrigação por aspersão e a eliminação manual de plantas daninhas.

Aos 57 dias após a semeadura, as mudas foram avaliadas nas seguintes características: altura da parte aérea; massa fresca da parte aérea e do sistema radicular e diâmetro do pseudocaule. Para a avaliação do sistema radicular, este foi separado da parte aérea com corte, lavado sob água corrente e secado com papel toalha.

O transplante ocorreu aos 57 dias após a semeadura, em solo cujo preparo foi o convencional, com enxada rotativa, no delineamento experimental de blocos casualizados, com três repetições. Os tratamentos foram arranjados segundo esquema fatorial $3 \times 3$, sendo três cultivares (Mercedes, Bola Precoce e Crioula), e três tipos de mudas (bandejas de poliestireno expandido com 200 e 288 células e mudas em sementeira).

Cada parcela constou de 4 fileiras com 2,0 m de comprimento cada uma, com plantas espaçadas $40 \mathrm{~cm}$ entre sulcos e $8 \mathrm{~cm}$ entre plantas, perfazendo 312.500 plantas por hectare. Aos 90 dias após o transplante, foram avaliadas em sete plantas ao acaso nas duas linhas centrais, as características de altura da parte aérea, número de folhas expandidas, diâmetro do pseudocaule e o número de plantas com bulbificação (considerando as com bulbos de no mínimo $2,0 \mathrm{~cm}$ de diâmetro).

A adubação em cobertura foi realizada com uréia na quantidade de 20 g. $\mathrm{m}^{-2}$, aos 80 dias do transplante. A área foi mantida com irrigação por aspersão.
A colheita foi realizada manualmente de acordo com a maturação das plantas, quando as plantas apresentaram acima de $70 \%$ de estalo, numa área de $0,25 \mathrm{~m}^{2}$.

Os bulbos foram curados por um período de 20 dias e preparados através dos cortes do sistema radicular e da parte aérea. Posteriormente, foram avaliados as características de peso total e peso médio. Foram considerados como tipo comercializável aqueles com diâmetro transversal acima de $35 \mathrm{~mm}$.

Foram determinados os custos de produção dos diferentes tipos de mudas e a sua viabilidade econômica.

Os dados foram submetidos à análise de variância e as médias comparadas pelo teste de Tukey no nível de $5 \%$ de probabilidade.

\section{RESULTADOS E DISCUSSÃO}

Em relação à altura de mudas (Tabela 1), a interação cultivar $\mathrm{x}$ tipos de mudas foi significativa. Desdobrando-se a interação, verificou-se diferença significativa entre cultivares somente quando as mudas foram obtidas em bandejas de 288 células, onde Mercedes foi superior a Crioula. Analisando os tipos de mudas, Mercedes e Bola Precoce apresentaram comportamento semelhante, onde os maiores valores foram encontrados nas bandejas de 200 e 288 células, diferindo significativamente das mudas obtidas em sementeira. Para Crioula, os três tipos de mudas apresentaram diferença significativa entre si, onde as de 200 células obtiveram destaque.

Para o diâmetro do colo (Tabela 1), houve efeito significativo apenas para tipos de mudas, sendo as obtidas em bandejas de 200 células superiores às demais apresentando diferença significativa entre si. Não foi observada diferença significativa entre cultivares.

TABELA 1 - Altura de mudas e diâmetro do colo aos 57 dias, em função do tipo de muda. UEPG. Ponta Grossa (PR), 2004.(B200=mudas produzidas em bandejas com 200 células; B288=mudas produzidas em bandejas com 288 células; Sement. $=$ mudas produzidas em sementeira).

\begin{tabular}{|c|c|c|c|c|c|c|c|c|}
\hline \multicolumn{4}{|c|}{ Altura (cm) } & \multicolumn{5}{|c|}{ Diâmetro do colo (mm) } \\
\hline $\begin{array}{c}\text { Tipos de } \\
\text { mudas }\end{array}$ & 'Mercedes' & $\begin{array}{c}\text { 'Bola } \\
\text { Precoce' }\end{array}$ & 'Crioula' & Média & 'Mercedes' & $\begin{array}{c}\text { 'Bola } \\
\text { Precoce' }\end{array}$ & 'Crioula' & Média \\
\hline $\mathrm{B} 200$ & $20,97 \mathrm{~A}^{*} \mathrm{a}^{*}$ & $19,93 \mathrm{~A} * \mathrm{a} *$ & $21,63 \mathrm{Aa}^{*}$ & 20,84 & 3,30 & 3,04 & 3,20 & $3,18 a^{*}$ \\
\hline B288 & $19,88 \mathrm{~A} \mathrm{a}$ & $17,32 \mathrm{AB}$ a & $14,27 \mathrm{Bb}$ & 17,16 & 3,06 & 2,63 & 2,52 & $2,74 \mathrm{~b}$ \\
\hline Sement. & $10,92 \mathrm{~A} \mathrm{~b}$ & $11,73 \mathrm{~A} \mathrm{~b}$ & $9,62 \mathrm{~A} \mathrm{c}$ & 10,76 & 1,55 & 1,83 & 1,77 & $1,72 \mathrm{c}$ \\
\hline Média & 17,26 & 16,33 & 15,17 & & $2,64 \mathrm{~A}^{*}$ & $2,50 \mathrm{~A}$ & $2,50 \mathrm{~A}$ & \\
\hline
\end{tabular}

*Médias seguidas da mesma letra maiúscula na linha e minúscula na coluna não diferem significativamente entre si no nível de $5 \%$ de probabilidade pelo teste de Tukey. 
A característica de massa fresca da parte aérea (Tabela 2) não apresentou interação significativa, tampouco o fator cultivar, de forma isolada. A diferença foi observada somente em relação aos tipos de mudas utilizadas, onde aquelas provenientes de bandejas de 200 células foram superiores às demais.

A massa fresca do sistema radicular (Tabela 2) apresentou interação significativa. Para cultivares, somente houve diferença significativa nas mudas obtidas em bandejas de 200 células, onde Mercedes foi inferior a Bola Precoce e Crioula. Para os tipos de mudas, as obtidas em bandejas de 200 células foram superiores e diferiram significativamente das mudas obtidas em bandejas de 288 células que, por sua vez, foram significativamente superiores às mudas de sementeira.

Cabe ressaltar a alta uniformidade das mudas obtidas em bandejas. O desenvolvimento na bandeja somente é restrito em função do volume da célula. Desta forma, a bandeja de 200 células, que tem células com maior volume e disponibilidade de nutrientes, demonstrou visualmente superioridade nas características de desenvolvimento comparada às mudas de 288 células, considerando o manejo empregado para a produção de mudas.

Por sua vez, as mudas de bandejas foram mais precoces em relação às da sementeira, beneficiado pelo ambiente de cultivo protegido, pois segundo Pereira \& Martinez (1999), esta é uma alternativa com o objetivo de otimizar o fornecimento dos fatores água, luz, temperatura, nutrientes, oxigênio, $\mathrm{CO}_{2}$ e genótipo, para expressão da máxima potencialidade genética das plantas.

A produção de mudas em sementeira apresenta maior competição entre as próprias mudas e plantas daninhas pelos fatores de crescimento, o que contribui para que o desenvolvimento das plantas seja desuniforme e o estande reduzido, acarretando em redução da qualidade do produto final.

Além disso, as mudas são submetidas a amplitudes térmicas variáveis e a temperaturas baixas nesta região. Conseqüentemente, o desenvolvimento das plântulas na sementeira, dificilmente acompanha o observado nas mudas de bandejas. Conforme Minami (1995), as sementes ficam em condições desuniformes (solo, chuvas, temperaturas extremas), o que proporciona germinação, emergência e crescimento das plântulas irregulares, levando à redução no estande e desuniformidade de produção.

No momento do transplante, deve-se selecionar as mudas sadias, uniformes e bem desenvolvidas, com altura de 15 a $20 \mathrm{~cm}$ e diâmetro de 0,6 a $0,8 \mathrm{~cm}$ (FONTES \& SILVA, 2002). No experimento, as mudas da sementeira apresentaram no momento do transplante aos 57 dias, altura de $10,76 \mathrm{~cm}$ e diâmetro do colo de $1,72 \mathrm{~mm}$, muito aquém do indicado pelos autores. As da bandeja, somente a altura apresentou-se dentro da faixa recomendada, enquanto o diâmetro foi inferior ao recomendado.

Considerando as médias das características avaliadas entre os tipos de mudas, observou-se a superioridade das mudas obtidas de bandejas, comparadas às da sementeira. Ainda, no sistema de bandejas, evidenciou-se a importância da utilização de bandejas com volumes maiores. Na bandeja com 200 células, o volume disponível para cada muda é de $16 \mathrm{~cm}^{3}$, enquanto que na bandeja com 288 células, o volume é de $10 \mathrm{~cm}^{3}$. E, segundo Leskokar (1998), alterando-se o volume de enraizamento das mudas, tem-se efeito no crescimento.

$\mathrm{Na}$ atualidade, para atuar num mercado competitivo, o produtor procura técnicas que agilizem e otimizem a produção. À medida que o preço da semente seja de custo

TABELA 2 - Massa fresca da parte aérea e do sistema radicular, em função do tipo de muda. UEPG. Ponta Grossa (PR), 2004. (B200=mudas produzidas em bandejas com 200 células; B288=mudas produzidas em bandejas com 288 células; Sement.=mudas produzidas em sementeira).

\begin{tabular}{|c|c|c|c|c|c|c|c|c|}
\hline & \multicolumn{4}{|c|}{ Massa fresca da parte aérea (g.planta ${ }^{-1}$ ) } & \multicolumn{4}{|c|}{ Massa fresca da raiz (g) } \\
\hline $\begin{array}{l}\text { Tipos de } \\
\text { mudas }\end{array}$ & 'Mercedes` & $\begin{array}{c}\text { Bola } \\
\text { Precoce' }\end{array}$ & 'Crioula' & Média & Mercedes` & $\begin{array}{c}\text { 'Bola } \\
\text { Precoce' }\end{array}$ & 'Crioula' & Média \\
\hline B200 & 0,64 & 0,72 & 0,69 & $0,68 a^{*}$ & $0,21 \mathrm{~B} \mathrm{a}^{*}$ & $0,30 \mathrm{~A}^{*} \mathrm{a}^{*}$ & $0,26 \mathrm{AB} * \mathrm{a} *$ & 0,26 \\
\hline B288 & 0,56 & 0,46 & 0,38 & $0,47 \mathrm{~b}$ & $0,15 \mathrm{~A} \mathrm{~b}$ & $0,16 \mathrm{~A} \mathrm{~b}$ & $0,20 \mathrm{~A} \mathrm{~b}$ & 0,17 \\
\hline Sement. & 0,21 & 0,20 & 0,18 & $0,20 \mathrm{c}$ & $0,07 \mathrm{~A} \mathrm{c}$ & $0,07 \mathrm{~A} \mathrm{c}$ & $0,06 \mathrm{~A} \mathrm{c}$ & 0,07 \\
\hline Média & $0,47 \mathrm{~A}^{*}$ & $0,46 \mathrm{~A}$ & $0,42 \mathrm{~A}$ & & 0,14 & 0,18 & 0,17 & \\
\hline
\end{tabular}

*Médias seguidas da mesma letra maiúscula na linha e minúscula na coluna não diferem significativamente entre si no nível de $5 \%$ de probabilidade pelo teste de Tukey. 
alto, o método da semeadura em sementeira, poderá ser substituído, considerando que o descarte de mudas ficou em torno de 50\%, o que é reiterado por Fontes \& Silva (2002), que observaram aproveitamento das mudas de 55 a $75 \%$.

Aos 90 dias do transplante (dat), foram analisadas as características de número de folhas, altura de plantas, diâmetro do pseudocaule e porcentagem de plantas com bulbificação.

Para o número de folhas (Tabela 3), houve interação significativa. Entre cultivares, observou-se diferença significativa somente na bandeja de 200 células para Mercedes, onde esta foi inferior a Bola Precoce e Crioula. Entre os tipos de mudas, Mercedes apresentou igual comportamento nos três tipos. Para Bola Precoce, houve destaque da bandeja de 200 células, superior aos demais tratamentos. Em Crioula, observou-se superioridade de mudas produzidas em bandejas, comparadas às de sementeira.

Para a altura (Tabela 3), não foi verificada interação significativa. Entre cultivares, Mercedes foi superior às demais apresentando 64,24 cm. Entre tipos de mudas, nas bandejas de 200 e 288 células a altura foi superior, diferindo estatisticamente da observada na sementeira.

$\mathrm{Na}$ Tabela 4 são mostradas características de diâmetro do pseudocaule e porcentagem de bulbificação. Para a primeira característica, não foi observada interação significativa. A diferença foi significativa somente para tipos de mudas, onde os maiores valores foram encontrados na bandeja de 200 células, diferindo apenas dos apresentados na sementeira.

TABELA 3 - Número de folhas e altura aos 90 dias do transplante, em função do tipo de muda. UEPG. Ponta Grossa (PR), 2004. (B200=mudas produzidas em bandejas com 200 células; B288=mudas produzidas em bandejas com 288 células; Sement.=mudas produzidas em sementeira).

\begin{tabular}{ccccccccc}
\hline \multicolumn{4}{c}{ Número de folhas } & \multicolumn{5}{c}{ Altura (cm) } \\
\hline $\begin{array}{c}\text { Tipos de } \\
\text { mudas }\end{array}$ & 'Mercedes' & $\begin{array}{c}\text { Bola } \\
\text { Precoce' }\end{array}$ & 'Crioula' & Média & 'Mercedes' & $\begin{array}{c}\text { 'Bola } \\
\text { Precoce' }\end{array}$ & 'Crioula' & 'Mercedes' \\
\hline B200 & $8,20 \mathrm{~B}^{*} \mathrm{a}^{*}$ & $10,07 \mathrm{~A}^{*} \mathrm{a} *$ & $9,87 \mathrm{~A}^{*} \mathrm{a}^{*}$ & 9,38 & 65,92 & 66,53 & 65,76 & $65,07 \mathrm{a}^{*}$ \\
B288 & $8,33 \mathrm{~A} \mathrm{a}$ & $9,00 \mathrm{~A} \mathrm{~b}$ & $9,27 \mathrm{~A} \mathrm{a}$ & 8,87 & 66,12 & 56,25 & 58,49 & $60,28 \mathrm{a}$ \\
Sement. & $7,80 \mathrm{~A} \mathrm{a}$ & $7,80 \mathrm{~A} \mathrm{c}$ & $8,00 \mathrm{~A} \mathrm{~b}$ & 7,87 & 60,67 & 44,77 & 43,75 & $49,73 \mathrm{~b}$ \\
\hline Média & 8,11 & 8,96 & 9,05 & & $64,24 \mathrm{~A}^{*}$ & $54,85 \mathrm{~B}$ & $56,00 \mathrm{~B}$ & \\
\hline
\end{tabular}

*Médias seguidas da mesma letra maiúscula na linha e minúscula na coluna não diferem significativamente entre si no nível de $5 \%$ de probabilidade pelo teste de Tukey.

TABELA 4 - Características de diâmetro do pseudocaule e porcentagem de plantas com bulbificação aos 90 dias do transplante, em função do tipo de muda. UEPG. Ponta Grossa (PR), 2004. (B200=mudas produzidas em bandejas com 200 células; B288=mudas produzidas em bandejas com 288 células; Sement.=mudas produzidas em sementeira).

\begin{tabular}{cccccccccc}
\hline \multicolumn{3}{c}{ Diâmetro do pseudocaule $(\mathbf{m m})$} & \multicolumn{5}{c}{ Plantas com bulbificação (\%) } \\
\hline $\begin{array}{c}\text { Tipos de } \\
\text { mudas }\end{array}$ & 'Mercedes' & $\begin{array}{c}\text { 'Bola } \\
\text { Precoce' }\end{array}$ & 'Crioula' & Média & 'Mercedes' & $\begin{array}{c}\text { 'Bola } \\
\text { Precoce' }\end{array}$ & 'Crioula' & Média \\
\hline B200 & 15,50 & 17,81 & 19,51 & 17,61 & $76,54 \mathrm{~A}^{*} \mathrm{a}^{*}$ & $12,85 \mathrm{~B}^{*} \mathrm{a}^{*}$ & $0,00 \mathrm{~B}^{*} \mathrm{a}^{*}$ & 29,80 \\
B288 & 14,72 & 14,77 & 16,91 & $15,46 \mathrm{ab}$ & $71,44 \mathrm{~A} \mathrm{a}$ & $5,26 \mathrm{~B} \mathrm{a}$ & $0,00 \mathrm{~B} \mathrm{a}$ & 25,57 \\
Sement. & 14,42 & 12,71 & 12,66 & $13,25 \mathrm{~b}$ & $35,85 \mathrm{~A} \mathrm{~b}$ & $0,00 \mathrm{~B} \mathrm{a}$ & $0,00 \mathrm{~B} \mathrm{a}$ & 11,95 \\
\hline Média & $14,88 \mathrm{~A}{ }^{*}$ & $15,09 \mathrm{~A}$ & $16,35 \mathrm{~A}$ & & 61,28 & 6,04 & 0,00 & \\
\hline
\end{tabular}

${ }^{\star}$ Médias seguidas da mesma letra maiúscula na linha e minúscula na coluna não diferem significativamente entre si no nível de 5\% de probabilidade pelo teste de Tukey. 
Quanto ao número de plantas bulbificadas aos 90 dias, a interação cultivar x tipo de muda foi significativa. Mercedes apresentou a maior porcentagem de bulbificação aos 90 dias após o transplante (dat), com 76,54\%, 71,44\% e $35,85 \%$, para bandeja de 200, 288 células e sementeira respectivamente, tendo sido o destaque para a característica. Não houve diferença significativa no percentual, entre as bandejas de 200 e 288 células. Bola Precoce apresentou baixa porcentagem de bulbificação aos 90 dat e essa ocorrência foi observada apenas nos tratamentos com mudas de bandejas. Por sua vez, Crioula foi o único material que não apresentou bulbificação aos 90 dat.

Observou-se diferença de precocidade para bulbificação entre as cultivares utilizadas. Mercedes foi a mais precoce, seguida de Bola Precoce, e Crioula foi a mais tardia, não apresentando nessa época plantas com bulbificação por ser material mais tardio, de dias intermediários e exigente em fotoperíodo longo. Esse comportamento corrobora a classificação de cultivares apresentada por Costa et al. (2002), o que foi confirmado também pelas épocas de colheitas realizadas aos 116 dias do transplante nos tratamentos (Mercedes x B200 e Mercedes x B288 células); aos 122 dias (Bola Precoce x B 200); aos 128 dias (Mercedes x sementeira e Bola Precoce x B 288); e aos 148 dias (Bola Precoce x sementeira, Crioula x B200, Crioula x B288 e Crioula x sementeira).

Observou-se que plantas menores provenientes de mudas obtidas em sementeira apresentaram porcentagem de bulbificação menor quando comparadas às plantas obtidas de bandejas. O desenvolvimento mais atrasado observado no estádio de mudas continuou se refletindo durante o desenvolvimento da planta. Dessa forma, a qualidade maior das mudas de bandejas, traduzida pelo tamanho maior, refletiram no desenvolvimento mais vigoroso aos 90 dat, quando comparadas às plantas provenientes do transplante de mudas de sementeira.

As diferenças observadas durante o desenvolvimento vegetativo entre os dois tipos de bandejas não foram tão pronunciadas, embora os valores da bandeja de 200 fossem sempre superiores aos da bandeja de 288 células, mas com diferença estatística apenas com os valores da sementeira. No entanto, essas diferenças refletiram e de forma mais acentuada no desempenho final da planta, ou seja no rendimento de bulbos. Para esta característica, não foi observada interação sgnificativa.

As cultivares Crioula e Mercedes foram as mais produtivas e diferiram significativamente de Bola Precoce, a menos produtiva (Tabela 5).

Para os tipos de mudas, houve superioridade no rendimento quando proveniente da bandeja de 200 células, seguida da bandeja de 288 células, com rendimento intermediário e, da sementeira, com o valor inferior. Estes resultados demonstram que a produtividade média estadual $\left(13,76\right.$ t.ha $\left.^{-1}\right)$ pode ser efetivamente aumentada com a estratégia de mudança no método de produção de mudas. Quando comparada à sementeira, a muda obtida da bandeja de 288 células produziu 7,15 t.ha $^{-1}$ a mais e a de 200 células, 22,31 t.ha-1 a mais. Maluf et al. (2003) não obtiveram produtividade contrastante quando compararam mudas obtidas de sementeira e de bandejas.

A produção de mudas em bandejas, embora seja uma técnica bastante especializada e aparentemente mais onerosa comparada à sementeira, diminui o risco de perda

TABELA 5 - Rendimento e peso médio de bulbos, em função do tipo de muda. UEPG. Ponta Grossa (PR), 2004. (B200=mudas produzidas em bandejas com 200 células; B288=mudas produzidas em bandejas com 288 células; Sement.=mudas produzidas em sementeira).

\begin{tabular}{|c|c|c|c|c|c|c|c|c|}
\hline \multicolumn{5}{|c|}{ Rendimento de bulbos (t.ha $\left.{ }^{-1}\right)$} & \multicolumn{4}{|c|}{ Peso médio de bulbos (g) } \\
\hline $\begin{array}{l}\text { Tipos de } \\
\text { mudas }\end{array}$ & 'Mercedes' & $\begin{array}{l}\text { 'Bola } \\
\text { Precoce' }\end{array}$ & 'Crioula' & Média & 'Mercedes' & $\begin{array}{l}\text { 'Bola } \\
\text { Precoce' }\end{array}$ & 'Crioula' & Média \\
\hline B 200 & 63,24 & 51,05 & 66,19 & $60,16 a^{*}$ & 197,61 & 159,52 & 206,85 & $187,99 \mathrm{a}^{*}$ \\
\hline B 288 & 44,70 & 36,84 & 53,48 & $45,00 \mathrm{~b}$ & 143,46 & 110,74 & 171,10 & $141,77 \mathrm{~b}$ \\
\hline Sement. & 43,36 & 26,93 & 43,26 & $37,85 \mathrm{c}$ & 148,43 & 84,16 & 135,19 & $123,04 \mathrm{~b}$ \\
\hline Média & $50,43 \mathrm{~A}^{*}$ & $38,27 \mathrm{~B}$ & $54,31 \mathrm{~A}$ & & $163,17 \mathrm{~A}^{*}$ & $118,15 \mathrm{~B}$ & $171,50 \mathrm{~A}$ & \\
\hline
\end{tabular}

*Médias seguidas da mesma letra maiúscula na linha e minúscula na coluna não diferem significativamente entre si no nível de $5 \%$ de probabilidade pelo teste de Tukey. 
de mudas e assegura a vantagem do maior rendimento e qualidade de bulbos.

Os resultados superiores de mudas de bandejas comparadas às mudas de sementeira também foram observados por Dellacecca et al. (2000) na Itália, assim como a superioridade do volume maior da célula, na Flórida e no Texas (LESKOVAR \& VAVRINA, 1999).

Mudas maiores provenientes das bandejas apresentaram maior produtividade e bulbos de maior tamanho. Cabe ressaltar que não foram encontrados bulbos com diâmetro inferior a $35 \mathrm{~mm}$. Essa é uma das grandes vantagens da muda produzida em bandeja. Além da garantia de obtenção de mudas de maior qualidade, esse atributo reflete-se no produto final, também de maior qualidade.

O tamanho do bulbo foi expresso através do peso médio dos bulbos (Tabela 5), cujos valores não apresentaram interação significativa. Observou-se superioridade do peso de bulbos na bandeja de 200 células $(187,99 \mathrm{~g})$ comparado aos demais tipos de mudas. Entre cultivares, Mercedes e Crioula apresentaram os maiores pesos, porém não apresentaram diferença significativa entre si. Essas diferiram de Bola Precoce que apresentou o menor valor.

Para o cálculo do custo de produção de mudas em sementeira, considerou-se a necessidade de $450 \mathrm{~m}^{2}$ para produzir mudas para um hectare (FONTES \& SILVA, 2002). Com a possibilidade de descarte de mudas no momento do transplante, utilizaram-se $675 \mathrm{~m}^{2}$ de área de sementeira e a densidade de 5,0 g.m $\mathrm{m}^{-2}$, o que totaliza $3,38 \mathrm{~kg}$ de semente. Sendo a semente da cultivar Crioula ou Bola Precoce, com custo de $\mathrm{R} \$ 327,00 . \mathrm{kg}^{-1}$, tem-se o total de $\mathrm{R} \$ 1.105,26$. No caso de usar a semente da cultivar híbrido $\left(\mathrm{R} \$ 781,20 . \mathrm{kg}^{-1}\right)$, o custo será de R $\$ 2.640,46$. Os preços de sementes foram informados pelas empresas mantenedoras das sementes.

Manutenção de duas pessoas contratadas para a atividade de produção de mudas, com salário mínimo rural de $\mathrm{R} \$ 340,00$, tendo-se o custo com mão-de-obra no período (60 dias), de $\mathrm{R} \$ 340,00 \times 2=\mathrm{R} \$ 680,00 \times 2$ meses $=\mathrm{R} \$ 1360,00$.

Pela somatória dos ítens, tem-se o custo de produção, quando se usa cultivar de polinização aberta e quando for o caso do híbrido Mercedes (Tabela 6).

Para o cálculo do custo de produção de mudas em bandejas de 200 e de 288 células, com uma população de plantas de 312.500 plantas.ha-1 ${ }^{-1}$, são necessários 1.562 bandejas de 200 células, com custo unitário de $\mathrm{R} \$ 5,00$. Considerando a utilização das bandejas por seis vezes, tem-se portanto, um custo de $\mathrm{R} \$ 1.301,67$ por safra. Para bandejas de 288 células, a necessidade será de 1.085 bandejas, com custo de $\mathrm{R} \$ 904,17$ por safra.

Para a produção dessas mudas, considerou-se a necessidade de uma estufa tipo túnel alto, com estrutura de pés de eucalipto e coberto com filme de polietileno de 150 micras, cujo custo por $\mathrm{m}^{2}$ na região é de $\mathrm{R} \$ 10,00$. Utilizando bandejas de 200 células, serão necessários 485,0 $\mathrm{m}^{2}$ de estufa, tendo em vista que cada $100 \mathrm{~m}^{2}$ de estufa, admitindo uma área útil de $75 \%$, comporta 322 bandejas (PEREIRA \& MARTINEZ, 1999). Dessa forma, tem-se o custo de $\mathrm{R} \$ 4.850,00$. Considerando o financiamento para dois anos, tem-se o desembolso de R $\$ 2.546,25$ por ano (embutidos $5 \%$ de juro). Para produção em bandejas de 288 células, serão necessários $337,0 \mathrm{~m}^{2}$ de estufa, com desembolso anual de $\mathrm{R} \$ 1.769,25$ (5\% de juro).

Tendo o custo do substrato Plantmax ${ }^{\circledR}$ de $\mathrm{R} \$ 8,50 /$ saco e que cada saco preenche 14 bandejas de 200 células, a necessidade será de 111 sacos, com custo de R \$944,00. Para 288 células, 1 saco preenchendo 18 bandejas, tem-se 60 sacos, com custo de R \$ 510,00.

Considerando que em 1,0 g tem-se aproximadamente 300 sementes, tem-se a necessidade de 1,03 kg de semente, que será aproximado para $1,1 \mathrm{~kg}$. Para cultivar de polinização aberta, o custo da semente será de $\mathrm{R} \$ 360,00$ e para o híbrido de $\mathrm{R} \$ 859,32$. A manutenção de 2 pessoas contratadas para a produção no período de dois meses, tem-se o custo de $\mathrm{R} \$ 1.360,00$. Pela somatória dos itens considerados, obtiveram-se os diferentes valores apresentados na Tabela 6 .

O custo de produção de mudas na bandeja foi efetivamente maior do que o observado na sementeira. Nas bandejas de 200 células, o custo foi maior que na de 288 células, pelo gasto maior em bandejas e em substrato e pela utilização de maior espaço físico. Além disso, o custo sempre foi maior com híbrido, em função do preço da semente. No caso de usar sementes de cultivares híbridos, evidenciou-se que a diferença de custo entre o sistema de produção de mudas em bandejas, comparada à sementeira não foi tão contrastante, o que favorece o primeiro sistema, com mudas de melhor qualidade, precoces e com menor gasto de semente.

$\mathrm{Na}$ sementeira, considerando o gasto maior de semente, descarte alto de mudas e risco maior de produção, não foram encontradas vantagens que respaldem suficientemente esse método.

O cultivo da cebola na maioria dos estados brasileiros está alicerçado na produção de mudas em sementeira e transplante destas mudas para o local definitivo (GUIMARÃES et al., 1997). Um dos fatores que contribui para o uso desse método é o custo para aquisição de sementes de cultivares nacionais como Crioula e Bola Precoce bastante inferiores ao preço da semente importada, principalmente de híbridos. Além disso, a utilização de genótipos nacionais é superior ao do importado. 
TABELA 6 - Valores dos custos de produção de mudas para um hectare (em R\$). UEPG. Ponta Grossa (PR). 2004.

\begin{tabular}{|c|c|c|}
\hline \multicolumn{3}{|c|}{ Custo de produção da muda $\left(\mathrm{R} \$ . h a^{-1}\right)$} \\
\hline Tipo de muda & 'Bola Precoce' ou 'Crioula' & Híbrido Mercedes \\
\hline Bandeja de 200 células & $6.511,92$ & $7.011,24$ \\
\hline Bandeja de 288 células & $4.903,42$ & $5.402,74$ \\
\hline Sementeira & $2.465,26$ & $4.000,46$ \\
\hline Média & $4.626,87$ & $5.472,81$ \\
\hline
\end{tabular}

Por outro lado, a produção de mudas de cebola em bandejas tem sido observada com cuidados, pois no campo, trata-se de uma cultura manejada com população de plantas por hectare acima de 300.000 , o que gera a necessidade de grande quantidade de mudas para transplante, associado ao fato que o tamanho da área utilizado para o cultivo da planta ser em média acima de 2,0 hectares (SEAB/DERAL, 2005). Além disso, a atividade de produção de mudas em bandejas exige um alto grau de profissionalização, fazendo com que, na prática, seja praticada por viveiristas e não por produtores de cebola.

Comparando os custos entre os sistemas de produção de mudas em bandejas e em sementeira para cultivar de polinização aberta, observou-se que a diferença é de $\mathrm{R} \$ 4.046,66$ a mais quando produzida em 200 células e de $\mathrm{R} \$ 2.438,16$ a mais quando obtida em 288 células. Considerando esse adicional no custo de produção e o preço médio de comercialização dos últimos cinco anos de $\mathrm{R} \$ 0,46 . \mathrm{kg}^{-1}$ (AGRIANUAL, 2004), é necessário um diferencial no rendimento de bulbos de 8,80 t.ha-1 para validar a produção de mudas em bandejas de 200 células e de 5,30 t.ha ${ }^{-1}$ na de 288 células.

Utilizando os valores de rendimento de bulbos para cada cultivar (Tabela 5), pode-se observar que Bola Precoce produziu 24,12 t.ha-1 a mais com mudas da bandeja de 200 células e 9,91 tha ${ }^{-1}$ com mudas da bandeja de 288 células. A cultivar Crioula apresentou um diferencial de 22,93 t.ha 1 a favor da muda produzida na bandeja de 200 células, enquanto este valor foi de 10,22 t.ha ${ }^{-1}$ utilizando mudas da bandeja de 288 células. Em ambos os casos, quando as mudas foram provenientes da bandeja de 200 células, os valores a favor desse tipo de muda encontram-se muito acima do diferencial. Para a muda de bandeja de 288 células, em ambos os casos, os valores também demonstram a viabilidade econômica do processo; no entanto, ficam muito aquém dos resultados apresentados pela muda da bandeja de 200 células. Embora com custo de produção mais elevado na bandeja de 200 células, a resposta promovida no aumento da produtividade valida o investimento.
Para o híbrido Mercedes, fazendo a mesma comparação, encontrou-se um custo adicional de R\$ $3.006,78$, para a bandeja de 200 células. Já no caso da bandeja de 288 células, o custo adicional encontrado foi de R\$1.398,28. Adotando o mesmo procedimento, para validar a utilização de mudas de bandejas de 200 e de 288 células, é necessário um diferencial de 6,54 t.ha- ${ }^{-1}$ e 3.04 t.ha ${ }^{-1}$, respectivamente. Para mudas obtidas em bandeja de 200 células, obteve-se superioridade produtiva de 19,88 t.ha-1 no rendimento de bulbos, o que valida o método. Já, em relação às bandejas de 288 células, o mesmo comportamento não foi observado, pois o diferencial no rendimento de bulbos foi de 1,34 t.ha-1.

Dessa forma, independentemente da cultivar, observou-se que a produção de mudas, principalmente em bandejas de 200 células, é uma técnica viável, podendo ser incorporada no sistema de cultivo da cebola.

\section{CONCLUSÕES}

Mudas de cebola provenientes de bandejas apresentaram superioridade nas características de número de folhas, altura, massa fresca da parte aérea e da raiz, diâmetro do colo e precocidade quando comparadas às mudas de sementeira, obtendo destaque as obtidas em bandejas de 200 células;

A muda obtida em sementeira não apresentou vantagem principalmente com híbrido, em que o custo da semente é maior que o da cultivar e sobretudo, pelo gasto maior de sementes na sementeira e baixo aproveitamento de mudas;

A produção de mudas em bandejas, principalmente na de 200 células, embora mais onerosa comparada à sementeira, demonstrou ser uma técnica viável e promissora para aumento da produtividade;

A produtividade das cultivares Crioula e Bola Precoce foram superiores com mudas provenientes de bandejas de 200 células; intermediária, com mudas de 
bandejas de 288 células, e inferior quando a muda foi proveniente de sementeira; Mercedes.

As cultivares mais produtivas foram Crioula e

\section{REFERÊNCIAS BIBLIOGRÁFICAS}

AGRIANUAL. Anuário da agricultura brasileira. São Paulo: FNP Consultoria e comércio, 2004. 512 p.

CARDOSO, A. I. I.; COSTA, C. P. Produção de bulbinhos de cebola em bandejas de isopor. Scientia Agricola, Piracicaba, v. 56, n. 4, p. 969-974, 1999.

COSTA, C. P. da. Olericultura brasileira: passado, presente e futuro. Horticultura Brasileira, Brasília, v. 18, p. 7-11, 2000. Suplemento.

COSTA, N. D.; LEITE, D. L.; SANTOS, C. A. F.; CANDEIA, J. A.; VIDIGAL, S. M. Cultivares de cebola. Informe Agropecuário, Belo Horizonte, v. 23, n. 218, p. 20-27, 2002.

DELLACECCA, V.; LOVATO, A. F. S.; STOFFELLA, P. J.; CANTLIFFE, D. J.; DAMATO, G. Effects of different plant densities and planting systems on onion (Allium cepa L.) bulb quality and yield. Acta Horticulturae, The Hague, n. 533, p. 197-203, 2000.

EMPRESA DE PESQUISA AGROPECUÁRIA DE SANTA CATARINA. Pesquisa testa novas técnicas para produção de mudas de cebola. Agropecuária Catarinense, Florianópolis, v. 8, n. 1, p. 25-28, 1995.

FAO. Dados Agrícolas de FAOSTAT: production, crops primary, onions. Disponível em: <http://apps.fao.org.>. Acesso em: 9 mar. 2004.

FONTES, P. C. R.; SILVA, D. J. H. Métodos de produção de cebola. Informe Agropecuário, Belo Horizonte, v. 23, n. 218, p. 28-35, 2002.

GUIMARÃES, D. R.; DITTRICH, L. T.; DITTRICH, R. C. Viabilidade técnica da semeadura direta para a cultura da cebola. Agropecuária Catarinense, Florianópolis, v. 10, n. 1, p. 57-61, 1997.

JAIME, M.; ROBERTS, L.; McDONALD, M. R. Growing onion transplants in plug trays. [S.1.]: Ministry of Agriculture and Food, 2001. Disponible in: <http:// www.gov.on.ca/OMAF/english/crops/facts/01-019.htm>. Access in: 7 out. 2004.
LATIMER, J. G. Container size and shape influence growth and landscape performance of marigold seedling. Hortscience, Alexandria, v. 26, p. 124-126, 1991.

LESKOKAR, D. I. Root and shoot modification by irrigation. Hort Technology, Alexandria, v. 8, p. 510-514, 1998.

LESKOVAR, D. I.; VAVRINA, C. S. Onion growth and yield are infuenced by transplant tray cell size and age. Scientia Horticulturae, Amsterdam, v. 80, n. 3/4, p. 133143, 1999.

LÓPEZ, M. V.; CHACÓN, J. L.; RAYA, J. L. Manejo en semillero de substratos para cultivo hidroponico: turba y fibra de coco. In: FERNANDÉZ, M. F.; GÓMEZ, I. M. C. (Eds.). Cultivos sin suello II. Almeria: DGIFA/FIAPA/Caja Rural de Almeria, 1999. p. 399-412.

MALUF, L. E. J.; SCHMIDT, P. A.; MADEIRA, N. R. Avaliação do sistema de produção de mudas de cebola em bandejas. Horticultura Brasileira, Brasília, v. 21, n. 2, 2003. CD-ROM.

MINAMI, K. Produção de mudas de alta qualidade em Horticultura. São Paulo: T. A. Queiroz, 1995. 135 p.

NICOLA, S.; BASOCU, L. Overhead, ebb and flow, and flotation: analysis of three irrigation systems to grow lettuce transplants. In: INTERNATIONAL SYMPHOSIUM ON PROTECTED CULTIVATION IM MILD WINTER CLIMATES: CURRENT TRENDS FOR SUSTAINABLE TECHNOLOGIES, 1., 2000, Cartagena. Abstracts... Cartagena: ISHS, 2000. p. 143.

OLIVEIRA, R. P.; SCIVITTARO, W. B.; VASCONCELLOS, L. A. B. C. Avaliação de mudas de maracujazeiro em função do substrato e do tipo de bandeja. Scientia Agrícola, Piracicaba, v. 50, n. 2, p. 261-266, 1993.

PEREIRA, P. R. G.; MARTINEZ, H. E. P. Produção de mudas para o cultivo de hortaliças em solo e hidroponia. Informe Agropecuário, Belo Horizonte, v. 20, n. 200/201, p. 24-31, set./dez. 1999.

SEAB/DERAL. Primeira estimativa para a safra de verão 05/06. 2005. Disponível em: <http//:www.pr.govbr/seab/ deral>. Acesso em: 17 out. 2005. 
ULLÉ, J. A. Comportamiento post-transplante de hortalizas de hojas y brassicaceas, provenientes de diferente volumen de contenedor y mezclas de substratos, a base de vermicomposto, turba, perlita. Horticultura Brasileira, Brasília, v. 19, 2001. CD-ROM.
VINCENZO, M. C. V.; TESSARIOLI NETO, J. Onion seedling production in styrofoam trays under controlled environment, as summer-planted onions. Scientia Agricola, Piracicaba, v. 60, n. 1, p. 65-69, 2003. 